\title{
CONTEXT AS A CREATIVE TOOLKIT FOR ARCHITECTURAL DESIGN: PERSPECTIVES OF MANAGEMENT AND SUSTAINABLE DEVELOPMENT OF URBAN HERITAGE
}

\author{
Eglè NAVICKIENE் (iD * \\ Vilnius Gediminas Technical University, Faculty of Architecture, \\ Department of Architecture, Traku str. 1, LT-01132 Vilnius, Lithuania
}

Received 29 November 2019; accepted 7 May 2020

\begin{abstract}
Integration into architectural or urban context as an evaluation criterion is claimed to be subjective and hardly substantiated. In spite of its ambiguity, it is generally accepted as one of the basic demands in architectural design. So what the context is in architectural design? The article explores specific understandings of architectural-urban context from characteristic perspectives in urban heritage protection and management. From perspective of architectural heritage protection, context is physical architectural objects nearby, perceived visually in a static mode, and respected in interventions by achieving harmonious relationship with it. From the point of view of cultural landscape, context is an interacting natural and man-made environment, constantly changing according to place-specific natural and cultural processes; its processual character and the accumulated meanings that rise from imbedded experiences ought to be continued in following architectural transformations. Historic urban landscape approach assumes that context is constantly developing through urbanization, cultural, social and economic processes, which cultural uniqueness and identity is saturated by place-based meanings, experiences and emotional relationships attributed by local community, ought to be contributed in present-day architectural transformations. From the point of view of sustainable development, context is an inherited cultural, social, material, economic resource and a source of traditional knowledge, performance and behaviours to be adapted and carried on towards a greater sensitivity to the environment, culture, climate, and place, and for the wellbeing of local community.
\end{abstract}

Keywords: architectural context, creative design, cultural heritage protection, historic urban landscape, protection and management of historic cities, sustainable development, urban context.

\section{Introduction}

Integration into context as a criterion of architectural quality was excluded from Law of the Republic of Lithuania on Construction as a subjective and hardly substantiated one that tends for diverse interpretations (Dūdènas, 2015, pp. 49-50; Lietuvos laisvosios rinkos institutas, 2015). In spite of its ambiguity, integration into context (or contextual approach) is generally accepted as one of the basic demands in architectural design. Consequently, it is one of the

*Corresponding author. E-mail: egle.navickiene@vgtu.lt 
main evaluation criteria in architecture competitions, ratings and assessments of architectural objects. The application of this criterion raises discussions among the peers what context is, what content does it comprise in architectural design? The conceptual disputes between researchers and architects in practice, among the representatives of the fields of architectural design, urban design and heritage protection, and even among the professionals of different generations point to the need of establishing the common ground in defining what context is as a shared conception and applicable tool in creative design and evaluation of architecture. So what the context is in architectural design?

The Oxford English Dictionary defines context as "the circumstances that form the setting for an event, statement, or idea, and in terms of which it can be fully understood" (Lexico.com, 2020). Applied for the field of architecture, the term architectural context (or urban context, or context for short) would indicate circumstances, conditions, setting, and environment for creative design or understanding architectural object. However, the toolkits attributed to the notion vary from case to case.

In order to avoid disciplinary fragmentation, and because the content of the notions of architectural context and urban context is often overlapping, the borderline between the notions is not toolkit, and a compound term - architectural-urban context - is used. It embraces architectural and urban elements that are interrelated and complementary; it contains hierarchical levels of architecture in its broadest sense and urbanism as an integral part of it; and focuses on the urban environment territorially and typologically.

The relevance and significance of architectural-urban context increases in changing of urban environment, and especially in situations where an environment features cultural significance and is protected legally. That is why the article focuses on architectural-urban context in architectural transformation of the historic urban environment that is protected under the status of urban heritage. The article explores and discusses perceptions concerning architectural-urban context from the perspectives in cultural heritage protection and its international development during the latter decades. Certain characteristic categories of cultural heritage protection and management that feature particular understanding of architectural-urban context are selected for the analysis: the initial stage of architectural heritage protection, the categories of cultural landscape and of historic urban landscape, and the growing relationship between heritage protection and sustainable development approach. Based on particular understandings of context in categories analysed, the article aims to investigate the relativity of context perception, to discuss the differences, and to synthesize definitions - each specified and the integral one - of architectural-urban context to be shared by architects, urban designers, and heritage protection professionals, and ready to be applied in design, critique and research.

The existing knowledge on certain categories of urban heritage protection is analysed in the review of international legal documents and scientific literature in order to synthesize the conceptual approach and fundamental guidelines concerning the context in each category. The theoretic framework enables the author to identify, argue and define the specific understanding of context from every perspective analysed. Comparative analysis of scope and content of context from diverse perspectives enables the author to explain the differences and to reveal the reasons for variety. The in-depth insights guide to identifying and 
defining what architectural-urban context is in architectural creativity as a common ground applicable definition.

The novelty of the research lies in the reasons for relativity of understanding of architectural-urban context disclosed and the in-depth insights on diversity of the concept provided. The author contributes most in specific understandings of architectural-urban context identified, explained and defined, and the integral definition of architectural-urban context specified applicable for professionals concerned.

\section{Architectural-urban context from the perspective of architectural heritage protection}

The milestone international legal documents for the protection of heritage, adopted by ICOMOS, UNESCO and Council of Europe in the 1960s and 1970s, established the approach that follows the European theory and practice of heritage protection in the 19th century and the most of the 20th century. It perceives the environment mainly by visual observation, grounded on the relic effect of classical rationalism that emphasizes the external observation of objects (Petrušonis, 2017, p. 13).

The review of international legal documents on built heritage protection from the 1960s and 1970s, and scientific literature analysing these issues, disclose the prevailing approach of that time. Cultural heritage sites of outstanding value, designated as cultural monuments and complexes, are protected. The material elements of cultural monuments and complexes are the repositories of the significance of the heritage objects. The basic evaluation criteria for cultural properties is authenticity that is expressed in form, materials, workmanship and setting; only the objects that meet the so-called "test of authenticity" express aesthetic and historic values (International Council on Monuments and Sites, 1965; Logan, 2004, p. 3; Araoz, 2011, p. 57). Therefore, the fundamental guidelines of the period point to the significance of physical substance and visible attributes of cultural monuments and complexes, and their environment. Objects qualified as cultural heritage are regarded to be stable and static (Munjeri, 2004, p. 13; van Oers, 2010, p. 13). Their protection is based on the principles of "do not harm" and minimum intervention, and on the intolerance to change (Logan, 2004, p. 3; Veldpaus \& Pereira Roders, 2014, p. 245; Araoz, 2011, p. 56).

So how architectural-urban context is understood and treated from the perspective of initial stage of architectural heritage protection? As aesthetic and historic values are the focal ones, the protected architectural heritage objects are treated as frozen forms and spaces, like museum showpieces, and the environment surrounding these objects turns to a beautiful picture that shapes the background. The understanding of built environment as a static architectural setting, perceived visually, outreaches the close proximity to the objects of architectural heritage. Extended to larger historic urban areas, international doctrine still focuses on architectural objects and excludes urban elements like spatial relationships, urban pattern, existing functions, natural elements and landscape. It is confusing, that even the international document for the protection of the natural landscape, "Recommendation Concerning the Safeguarding of Beauty and Character of Landscapes and Sites" (United Nations Educational, Scientific and Cultural Organisation, 1963), declares protection of landscape aimed to safe- 
guarding its original condition, identifying it with a beautiful scenery, a "picture", and treated as static object (Jokilehto, 2010, p. 60).

The interpretation of architectural-urban context mostly by the categories of visual relationships and aesthetic parameters is symptomatic in the professional architectural literature of that time. For example, in his book on architecture in context, Brolin characterizes the historic urban environment as a visually harmonious neighbourhood, an environment with a unique aesthetic character, visually rich cohesive street spaces; he recommends to achieve harmonious relationship with it through "an intelligent, sensitive appraisal of the visual cues of the context" (1980, p. 140).

The scope of architectural-urban context from the perspective of international doctrine of architectural heritage protection in the 1960s and 1970s, and to some extent later, is fragmented and finite. The architectural-urban context to be regarded for its transformations, is a toolkit of surrounding physical architectural objects, perceived visually and protected from change. The content of architectural-urban context is narrowed up to physical substance (or, moreover, to its representative image) of urban built environment that mainly comprises architectural components, and is limited up to the dimension of visual perception. By excluding the components of urban structure and natural landscape, architectural-urban context - an environment that changes - is isolated from the driving forces of society and nature, and is treated as a fragmented and static representative picture. Being confined to the tangible elements and excluding non-material expressions, it does not take into account cultural circumstances and contribution of generations who have created it. The fragmented and "monochromatic" view of what constitutes architectural character of the surrounding context results in superficial contextual approach in architectural design, and architectural interventions that feature clumsy relationship to their surroundings.

\section{Architectural-urban context according to the approach of cultural landscape}

Since 1980-1990s, the statements of International Council on Monuments and Sites (1965) were reviewed by national committees of ICOMOS of the New World countries and were adapted to their specific multicultural situation:

"the people in their environment [...] are a human and social treasure that also requires protection" (International Council on Monuments and Sites, 2011b).

"Urban historical sites are part of a wider totality, comprising the natural and the built environment and the everyday living experience of their dwellers as well" (International Council on Monuments and Sites, 1987).

The revision of the main principles of cultural heritage protection and management grounded the concept of cultural landscape. At the turn of the century, it becomes a new category of cultural heritage, encompassing "the combined works of nature and of man" (United Nations Educational, Scientific and Cultural Organisation, 1994). It joins cultural heritage and landscape together, as European Landscape Convention defines landscape as "an area, as perceived by people, whose character is the result of the action and interaction of natural and/or human factors" (Council of Europe, 2000). 
The scientific literature on the topic considers the concept of cultural landscape as a challenge to predominating conventional theories and management models. The new heritage category is comprehended as the one that regards the environment as a living, dynamic and ever-changing system, that is considered from a cultural, socioeconomic, ecological, and urban point of view, and that needs to be managed as such and not simply preserved (Veldpaus \& Pereira Roders, 2014, p. 246; Jokilehto, 2010, p. 60; Rodwell, 2012, p. 77). It is acknowledged that cultural significance lies in the processes and experiences of local people, of those who have created and sustained them, in addition to authentic physical elements (Rodwell, 2010, p. 101; Taylor et al., 2015, p. 4). Therefore, the cultural landscape is both a dynamic cultural process and a socio-cultural construct that is an important part of national, regional and local identity and is closely related to morphology, history, memory, myths, and meanings (Veldpaus \& Pereira Roders, 2014, p. 246; Taylor, 2017).

Brief reflection of concept of cultural landscape, which includes also the historic cities, enables to understand the reasons for the broadening of the scope of architectural-urban context for new architectural interventions. From the perspective of protection and management of cultural landscape, the architectural-urban context is the environment that changes constantly, that is perceived not only by visual observation but also by "reading a story" of human experience; and which physical form is saturated by social dimension - signs of believes, memories and behaviour. According to the landscape-based approach, the architectural-urban context includes two parts that supplement each other. The first one is the material substance that covers its visible elements; it is no longer static, anchored at present, but it is perceived in the flow of time. The second part is the human experience and the meanings that embody it; if recognised and read carefully, they reveal the reasons for the peculiarities of its development, and, through the causal relationships, explain its specific nature. Combined together, material and intangible elements express the unique character of place that is created by place-specific modes and patterns.

From the standpoint of cultural landscape, the processual nature of development of urban setting is of a particular importance. Spatial and cultural layering of legacy of previous generations can be read from the composition and structure of a place or region. The historic architectural-urban context for the new developments is no longer a protected frozen setting where new architectural interventions are opposed to authentic legacy. Its change is an on-going process that is based on the knowledge and continuity of inherited models of place-specific experiences and human behaviours. Architectural-urban context is a treasury of settled traditions and patterns, and the main task for contextual approach in architectural design of interventions is to recognise, identify and interpret these treasures for a harmonious contribution and continuous evolution.

\section{Architectural-urban context according to the approach of historic urban landscape}

The historic urban landscape approach derived from the concept of the cultural landscape, it was adapted and developed for the historic cities of exceptional universal value. The concept of historic urban landscape was introduced in Vienna Memorandum on "World Heritage 
and Contemporary Architecture - Managing the Historic Urban Landscape" (United Nations Educational, Scientific and Cultural Organisation, 2005). It states:

\begin{abstract}
"the historic urban landscape acquires its exceptional and universal significance from a gradual evolutionary, as well as planned territorial development over a relevant period of time through processes of urbanization, incorporating environmental and topographic conditions and expressing economic and socio-cultural values pertaining to societies" (United Nations Educational, Scientific and Cultural Organisation, 2005).
\end{abstract}

The scope of historic urban landscape goes beyond the ones of protection of architectural heritage, urban heritage and cultural landscape. Historic urban landscape includes natural and man-made elements, moreover,
"its land use patterns and spatial organization, perceptions and visual relationships, as well as all other elements of the urban structure. It also includes social and cultural practices and values, economic processes and the intangible dimensions of heritage as related to diversity and identity" (United Nations Educational, Scientific and Cultural Organisation, 2011).

The focus on maintaining and promoting cultural, social and functional diversity (United Nations Educational, Scientific and Cultural Organisation, 2011) requires to ensure the creative continuity of its cultural uniqueness from past to present. Change is being managed by using heritage as a driver for urban development (Veldpaus \& Pereira Roders, 2014, p. 246). The multifaceted concept of the historic urban landscape is indicated by a wide spectrum of cultural values attributed: aesthetic, social, spiritual, memory, historic, age, economic, political, scientific, and ecological (Ginzarly \& Teller, 2018, p. 6; Veldpaus \& Pereira Roders, 2014, p. 253).

Among the components and values that are newly attributed to historic urban areas, intangible dimensions of heritage (United Nations Educational, Scientific and Cultural Organisation, 2003) and the spiritual values that contribute by giving meaning, emotion and mystery to place (International Council on Monuments and Sites, 2008) should be pointed out as one of the most significant ones. As it is discussed in scientific literature, the experiential and emotional connection of communities and individuals to a place covers complex and overlapping relationships like spirit of place, sense of place, identity of place, and place attachment (Čepaitienè, 2014), like collective memories, cultural meanings and associations, attributed to a place. Collective memories, personal remembrances, and meanings are projected onto present situation of a place:

"there is a mental image for every memory, and, consequently, images are claimed responsible for constructing and recalling both individual and collective memories" (Kamel-Ahmed, 2015, p. 72).

Briefly disclosed historic urban landscape approach enables us to reflect on specific understanding of the architectural-urban context from this particular standpoint. Compared to cultural landscape approach, the historic urban landscape approach expands its scope, which affects the understanding of context, towards two directions. Firstly, the historic urban landscape approach aims to balance the priorities of the protection and management of historic city, and the priorities of cultural, social and economic goals of city development, instead of opposing them. Urban transformations of historic city cannot be managed sepa- 
rately from its social and cultural practices, or economic processes. The holistic approach highlights the importance of positive acceptance of these transformations in society; consequently, it gives more grounds for pro-active public engagement in considering architectural projects for new buildings or public spaces that transform the places that the local communities are connected to, and, accordingly, are guarding them. Secondly, it adds experiential and emotional relationships to the environment: how communities and individuals feel and experience their environment, how they identify and attach themselves to it, and what meanings and associations it brings. These connections, individual or shared by community, add new components in perceiving the architectural-urban context. If revealed and embodied, meanings that rise from experiences and emotional relationships ensure the rootedness for architectural interventions into context. As Finnish architect Juhani Pallasmaa poetizes, "meaning cannot be invented; it can only be re-discovered, re-identified and re-articulated" (Martin \& Ricardo, 2016).

The historic urban landscape approach expands the understanding of architectural-urban context as the fundamental and creative inspiration for design of new interventions; besides, it provides more tools for perception of built environment to its designer, user or observer. If all the elements of architectural-urban context concerned are identified, maintained and interpreted during the transformations in a present-day manner, cultural uniqueness is safeguarded. These elements cover physical objects, visual relationships, structural and compositional patterns of urban environment that are related to collective memory and associations, and are expressed through people's experiential and emotional connection to place. This is of particular importance in understanding the significance of urban heritage to city's identity. As city's identity is a social and cultural construct, it is enriched, when architectural-urban context is articulated thoroughly and carefully in its full scope and content.

\section{Architectural-urban context as a resource for sustainable development}

Our Common Future: World Commission on Environment and Development, also known as the Brundtland Commission report, set the concept of sustainable development: "sustainable development is development that meets the needs of the present without compromising the ability of future generations to meet their own needs" (Brundtland, 1987, p. 41). Three initial domains of sustainable development defined as pillars - economic development, social development and environmental protection - under the UNESCO initiative were supplemented by culture realm. Culture is seen either the fourth pillar of sustainable development (United Nations 2002), or it is claimed as a key component, enabler and driver of sustainable development (United Nations, 2014). Cultural heritage plays an important role in social cohesion, well-being, creativity, and economic appeal, and it is a factor in promoting understanding between communities (International Council on Monuments and Sites, 2011a).

Literature review reveals that sustainable development approach transcends the boundaries of a single discipline of heritage as it calls for a holistic outlook and a completely new toolkit of behaviour (Boccardi \& Scott, 2018, p. 32). The approach demands that historic cities should be managed only in conjunction with all the domains of sustainable development. Inclusive social development of historic cities enhances the quality of life for local 
communities: through the promotion of cultural diversity and social cohesion, through the improvement of their abilities and opportunities, and through retaining their prevailing way of life. Participation of local communities and their contribution to heritage management is crucial (Hosagrahar, 2018). Inclusive economic development treats historic cities as cultural capital that generates economic growth, employment, income and livelihoods, stimulates economic investment, innovation and sustainable quality tourism, activates local opportunities and vitalizes construction and service industries (Ost, 2018; Pereira Roders \& van Oers, 2011, p. 9). Due to their long life cycle, historic buildings contribute to environmental protection by reducing the energy associated with built forms, through minimising the consumption of new energy and raw materials by adaptive reuse (Siebrandt et al., 2017, p. 4; Auclair \& Fairclough, 2015, p. 3). From the perspective of sustainable development, cultural heritage is much more than resource - it is a source of knowledge and experience to be continued, which, if investigated deeper, can provide answers to many questions we face nowadays:

"heritage is a central thread of sustainability, not only as an issue of preservation but of creation, adaptation and resilience to change" (Auclair \& Fairclough, 2015, p. 3).

Let us try to identify and define the changes of scope of architectural-urban context from the standpoint of sustainable development compared to the approaches discussed earlier. In spite of expansion up to social, economic and environmental domains, the significance of historic city is shrinking from the importance to global society down to the one for local community. The reason lies in the focus that was diverted from protection of urban heritage as a tool for the tourist industry. The relationship between environment and local community, the opportunities that heritage opens up, and the meanings it comprises, as they determine who a community is, what kind of behaviour models it is based on, and how it builds its future, matters instead. Local communities engage with the past in order to survive the present and create the future. Besides sociocultural aspects, environmental concerns also point the attention to tradition as a key to solve global environmental problems by acting locally.

"Traditional historic buildings are a treasury of architectural experience. They are an inexhaustible universal source of inspiration for modern and innovative architecture, in terms of materials, construction methods, layout and design, contributing to a high quality of life" (International Council on Monuments and Sites, 2011a).

Traditional and historic architecture in the context, that is the result from many centuries of observation and practical adjustments, teaches how to root in a particular place by responding to its specific environmental, socioeconomic, cultural, and climatic conditions.

From the point of view of sustainable development, architects should treat the architectural-urban context as the starting point and the fundamental for architectural design of interventions in any situation, it makes no difference whether historic urban area is protected as an urban heritage object, or not. Urban environment integrates miscellaneous factors: it creates local spirit and identity, conveys knowledge and skills, carries on the tradition, contributes to environmental concerns, and increases the attractiveness and competitiveness of the region through building stock and labour market. The concept of sustainability establishes new comprehension of urban environment, and, consequently, of architectural-urban context for on-going transformations, which puts people and their well-being at the core of interconnected network of social, cultural, environmental and economic realms. 


\section{Specific understandings of architectural-urban context articulated in definitions}

Summarising the investigation of architectural-urban context from particular perspectives in protection and management of urban heritage, identified scope and content is detailed in Table 1, and the specified definitions of architectural-urban context with the way of dealing with it are presented below. They articulate the differences in understanding what architectural-urban context is from the perspectives analysed.

From perspective of initial stage of architectural heritage protection, architectural-urban context is physical architectural objects nearby, perceived visually in a static mode and illustrative manner, and respected in interventions by achieving harmonious relationship with it.

From the point of view of the category of cultural landscape, architectural-urban context is an interacting natural and man-made environment, constantly changing according to place-specific natural and cultural processes; its processual character and the accumulated meanings that rise from imbedded experiences ought to be continued in following architectural transformations.

Table 1. Architectural-urban context and contextual approach in architectural design from perspectives of initial stage of architectural heritage protection, category of cultural landscape, category of historic urban landscape and the relationship between heritage protection and sustainable development (source: created by author)

\begin{tabular}{|c|c|c|c|c|c|}
\hline & $\begin{array}{l}\text { Initial stage of } \\
\text { architectural } \\
\text { heritage } \\
\text { protection }\end{array}$ & $\begin{array}{c}\text { Category of } \\
\text { cultural landscape }\end{array}$ & $\begin{array}{l}\text { Historic urban } \\
\text { landscape } \\
\text { approach }\end{array}$ & $\begin{array}{l}\text { Relationship } \\
\text { between heritage } \\
\text { protection and } \\
\text { sustainable } \\
\text { development }\end{array}$ \\
\hline \multirow{4}{*}{ 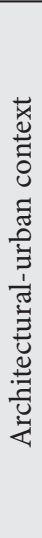 } & Scope & $\begin{array}{l}\text { Proximate built } \\
\text { environment }\end{array}$ & $\begin{array}{l}\text { Natural and } \\
\text { anthropogenic } \\
\text { environment }\end{array}$ & $\begin{array}{l}\text { Environment, } \\
\text { social and } \\
\text { cultural practices, } \\
\text { economic } \\
\text { processes }\end{array}$ & $\begin{array}{l}\text { Social, cultural, } \\
\text { environmental } \\
\text { and economic } \\
\text { domains }\end{array}$ \\
\hline & Components & $\begin{array}{l}\text { Architectural } \\
\text { objects }\end{array}$ & $\begin{array}{l}\text { Natural and } \\
\text { man-made } \\
\text { objects, processes, } \\
\text { meanings }\end{array}$ & $\begin{array}{l}\text { Natural and } \\
\text { man-made } \\
\text { objects, processes, } \\
\text { meanings, } \\
\text { emotional } \\
\text { connection }\end{array}$ & $\begin{array}{l}\text { Traditional } \\
\text { knowledge, } \\
\text { performance } \\
\text { and behaviours; } \\
\text { material resource }\end{array}$ \\
\hline & Expression & Material & $\begin{array}{l}\text { Material and } \\
\text { intangible }\end{array}$ & $\begin{array}{l}\text { Intangible and } \\
\text { material }\end{array}$ & $\begin{array}{l}\text { Intangible and } \\
\text { material }\end{array}$ \\
\hline & Mode & Static & Dynamic & Dynamic & Dynamic \\
\hline \multicolumn{2}{|c|}{$\begin{array}{c}\text { Contextual approach } \\
\text { in architectural } \\
\text { design }\end{array}$} & $\begin{array}{l}\text { Fitting into } \\
\text { context by } \\
\text { a visual } \\
\text { harmonious } \\
\text { relationship }\end{array}$ & $\begin{array}{l}\text { Continuity } \\
\text { of processual } \\
\text { character and } \\
\text { human experiences }\end{array}$ & $\begin{array}{l}\text { Contribution to } \\
\text { processes and } \\
\text { patterns, cultural } \\
\text { uniqueness and } \\
\text { identity }\end{array}$ & $\begin{array}{l}\text { Reactivating of } \\
\text { rooted order and } \\
\text { interrelations }\end{array}$ \\
\hline
\end{tabular}


From the perspective of historic urban landscape approach, architectural-urban context is constantly developing through urbanization, cultural, social and economic processes, which cultural uniqueness and identity is saturated by place-based meanings, experiences and emotional relationships attributed by communities, ought to be contributed in present-day architectural transformations.

From the point of view of the relationship between heritage protection and sustainable development, architectural-urban context is an inherited cultural, social, material, economic resource and a source of traditional knowledge, performance and behaviours to be adapted and carried on towards a greater sensitivity to the environment, culture, climate, and place, and for the wellbeing of community.

\section{Discussion and conclusions}

The particular standpoints of categories of urban heritage and its relationship to sustainable development analysed in the paper, enabled to define and explain the distinctions in the understanding what architectural-urban context is, as a specific relational toolkit that comprises these components and meanings that are attributed by specific cultural heritage attitude. Supposedly, the understanding of architectural-urban context would be even more diverse, if analysed from the other perspectives. Deterministic relationship between the understanding of architectural-urban context and the specific standpoint in the field of urban heritage protection explains the diversity. The ambiguity of the notion of context arises when diversity of understandings, if considered from different standpoints, is neglected, or when the dynamic nature of miscellaneous interweaving factors caused by ever-changing ways of dealing with urban heritage, is not taken into account.

At present the approach to architectural-urban context reaches far beyond architectural and urban aspects. New models of behaviour are encouraged. Architectural-urban context for transformations should be treated only in a multidisciplinary way, in coherence with cultural processes and products, with experiences and needs of community and society, and economic and environmental factors.

Based on the identified concepts from the perspectives of initial stage of architectural heritage protection, category of cultural landscape, historic urban landscape approach and the relationship between heritage protection and sustainable development that are defined above, the author generalises the integral definition of context. Generalised definition of architectural-urban context points to the surrounding historic urban landscape that is constantly developing through urbanisation, cultural, social, and economic processes based on established local knowledge, performance and behaviour models, which uniqueness is saturated by placebased meanings and relationships attributed by local community, and ought to be contributed in present-day architectural transformations. The definition could be shared and applied in creative design, critique and evaluation of architecture by researchers and professionals in creative practice. 


\section{References}

Araoz, G. F. (2011). Preserving heritage places under a new paradigm. Journal of Cultural Heritage Management and Sustainable Development, 1(1), 55-60. https://doi.org/10.1108/20441261111129933

Auclair, E., \& Fairclough, G. (2015). Living between past and future: an introduction to heritage and cultural sustainability. In E. Auclair \& G. Fairclough (Eds.), Theory and practice in heritage and sustainability: between past and future (pp. 1-22). Series: Routledge Studies in Culture and Sustainable Development. K. Soini \& J. Dessein (Series Eds.). Routledge. https://doi.org/10.4324/9781315771618-1

Boccardi, G., \& Scott, L. (2018). A view from the inside: an account of the process leading to the adoption of the policy for the integration of a sustainable development perspective within the world heritage convention. In P. B. Larsen \& W. Logan (Eds.), World heritage and sustainable development: new directions in world heritage management (pp. 21-36). Series: Key Issues in Cultural Heritage. W. Logan \& L. Smith (Series Eds.). Routledge. https://doi.org/10.4324/9781315108049-2

Brolin, B. C. (1980). Architecture in context: fitting new buildings with old. Van Nostrand Reinhold Company.

Brundtland, G. H. (Chairman of the Commission). (1987). Our common future: the world commission on environment and development. Oxford University Press.

Council of Europe. (2000, 20 October). European Landscape Convention. European Treaty Series No. 176. European Landscape Convention. Florence. https://rm.coe.int/1680080621

Čepaitienė, R. (Sud.). (2014). Vietos dvasia: prijaukinimas ar medžioklè? Iš R. Čepaitienė (Sud.), Vietos dvasios beieškant: straipsniu rinkinys (pp. 22-72). Lietuvos istorijos instituto leidykla.

Dūdènas, J. (2015). Esminių architektūros kokybès kriterijų sąrašo struktūra. Metodologiniai aspektai. Iš L. Nekrošius, V. Petrušonis, \& E. Riaubienè (Sud.), Architektūros kokybès kriterijai: mokslo straipsniu rinkinys (pp. 40-61). Serija: Architektūra: objektai ir kontekstai. T. 1. Vilnius: Technika.

Ginzarly, M., \& Teller, J. (2018). Eliciting cultural heritage values: landscape preferences versus representative images of the city. Journal of Cultural Heritage Management and Sustainable Development, 8(3), 257-275. https://doi.org/10.1108/JCHMSD-06-2017-0031

Hosagrahar, J. (2018). Inclusive social development and world heritage in urban areas. In P. B. Larsen \& W. Logan (Eds.), World heritage and sustainable development: new directions in world heritage management (pp. 68-86). Series: Key Issues in Cultural Heritage. W. Logan \& L. Smith (Series Eds.). Routledge. https://doi.org/10.4324/9781315108049-5

International Council on Monuments and Sites. (2011a). The Paris Declaration on heritage as a driver of development. 17th Assemblée Générale. Paris, France. https://www.icomos.org/Paris2011/ GA2011_Declaration_de_Paris_EN_20120109.pdf

International Council on Monuments and Sites. (2011b). Charter for the Preservation of Quebec's Heritage (Deschambault Declaration), 1982. https://www.icomos.org/en/support-us/179-articles-enfrancais/ressources/charters-and-standards/192-the-deschambault-charter

International Council on Monuments and Sites. (1987). First Brazilian Seminar about the preservation and revitalization of historic centers. Itaipava, 1987. 1st Brazilian Seminar about the Preservation and Revitalization of Historic Centers. Itaipava, Brazil. https://www.icomos.org/en/charters-andother-doctrinal-texts/179-articles-en-francais/ressources/charters-and-standards/194-first-brazilian-seminar-about-the-preservation-and-revitalization-of-historic-centers-itaipava

International Council on Monuments and Sites. (1965). International Charter for the Conservation and Restoration of Monuments and Sites (The Venice Charter 1964). 2nd International Congress of Architects and Technicians of Historic Monuments. Venice, Italy. https://www.icomos.org/charters/venice_e.pdf

International Council on Monuments and Sites. (2008). Québec Declaration on the Preservation of the Spirit of Place. https://whc.unesco.org/uploads/activities/documents/activity-646-2.pdf

Jokilehto, J. (2010). Reflection on historic urban landscapes as a tool for conservation. In R. van Oers \& S. Haraguchi (Eds.), World Heritage Papers. No. 27: Managing Historic Cities (pp. 53-63). UNESCO World Heritage Centre. 
Kamel-Ahmed, E. (2015). What to conserve? Heritage, memory, and management of meanings. ArchNet International Journal of Architectural Research, 9(1), 67-76. https://doi.org/10.26687/archnet-ijar.v9i1.469

Lexico.com. (2020). Context. https://www.lexico.com/definition/context

Lietuvos laisvosios rinkos institutas. (2015). Ekspertizè dèl architektūros įstatymo projekto. https://www. llri.lt/naujienos/ekonomine-politika/ekspertize-4/lrinka

Logan, W. (2004). Introduction. Voices from the periphery: The Burra Charter in context. Historic Environment, 18(1), 2-8.

Martin, C., \& Ricardo, R. R. (2016). Juhani Pallasmaa: experiencing slowness. Landscape Architecture Australia. https://landscapeaustralia.com/articles/juhani-pallasmaa-interview/

Munjeri, D. (2004). Tangible and intangible heritage: from difference to convergence. Museum International, 56(1-2), 12-20. https://doi.org/10.1111/j.1350-0775.2004.00453.x

Oers, van R. (2010). Managing cities and the historic urban landscape initiative - an introduction. In R. van Oers \& S. Haraguchi (Eds.), World Heritage Papers. No. 27: Managing Historic Cities (pp. 7-17). UNESCO World Heritage Centre.

Ost, Ch. (2018). Inclusive economic development in the urban heritage context. in P. B. Larsen \& W. Logan (Eds.), World heritage and sustainable development: new directions in world heritage management (pp. 53-67). Series: Key Issues in Cultural Heritage. W. Logan \& L. Smith (Series Eds.). Routledge. https://doi.org/10.4324/9781315108049-4

Pereira Roders, A., \& Oers, van R. (2011). Editorial: Bridging Cultural Heritage and Sustainable Development. Journal of Cultural Heritage Management and Sustainable Development, 1(1), 5-14. https://doi.org/10.1108/20441261111129898

Petrušonis, V. (2017). Nauja kultūros paveldo objektų aprašo koncepcija. Iš V. Almonaitytė-Navickienė (Sud.), Paveldo brydès (pp. 8-28). Savastis.

Rodwell, D. (2010). Historic urban landscapes: concept and management. In R. van Oers \& S. Haraguchi (Eds.), World Heritage Papers. No. 27: Managing Historic Cities (pp. 99-104). UNESCO World Heritage Centre.

Rodwell, D. (2012). The UNESCO World Heritage Convention, 1972-2012: reflections and directions. The Historic Environment: Policy and Practice, 3(1), 64-85. https://doi.org/10.1179/1756750512Z.0000000004

Siebrandt, D., Kraak, A.-L., James, L., \& Saldin, M. (2017). Editorial: heritage, sustainability and social justice. Historic Environment, 29(3), 2-10.

Taylor, K. (2017). Landscape, culture and heritage: changing perspectives in an Asian context (PhD/Doctoral Thesis). Deakin University, Victoria, Australia. http://dro.deakin.edu.au/eserv/DU:30102152/ taylor-landscapeculture-2017A.pdf

Taylor, K., Clair, St A., \& Mitchell, N. J. (2015). Introduction. Cultural landscapes: twenty-first century conservation opportunities and challenges. In K. Taylor, A. St Clair, \& N. J. Mitchell (Eds.), Conserving cultural landscapes: challenges and new directions (pp. 1-25). Series: Routledge Studies in Heritage. Routledge. https://doi.org/10.4324/9781315813226

United Nations. (2002, 26 August-4 September). Report of the World Summit on Sustainable Development. World Summit on Sustainable Development. Johannesburg, South Africa. United Nations.

United Nations. (2014, 20 December). Resolution Adopted by the General Assembly on 20 December 2013. General Assembly, 68th Session. https://www.un.org/ga/search/view_doc.asp?symbol=A/RES/68/223

United Nations Educational, Scientific and Cultural Organisation. (1994). Operational guidelines for the implementation of the World Heritage Convention. https://whc.unesco.org/archive/opguide94.pdf

United Nations Educational, Scientific and Cultural Organisation. (1963). Recommendation concerning the safeguarding of the beauty and character of landscapes and sites. Records of the General 
Conference, 12th Session (pp. 139-142). Vol.: Resolutions. General Conference. 12th Session, 1962. Paris, France. United Nations Educational, Scientific and Cultural Organisation.

United Nations Educational, Scientific and Cultural Organisation. (2011). Recommendation on the historic urban landscape, including a glossary of definitions. http://portal.unesco.org/en/ev.php-URL_ ID=48857\&URL_DO=DO_TOPIC\&URL_SECTION=201.html

United Nations Educational, Scientific and Cultural Organisation. (2003). Text of the Convention for the safeguarding of the intangible cultural heritage. https://ich.unesco.org/en/convention

United Nations Educational, Scientific and Cultural Organisation. (2005). Vienna Memorandum on "World Heritage and Contemporary Architecture - Managing the Historic Urban Landscape". Vienna, Austria. whc.unesco.org/document/6814

Veldpaus, L., \& Pereira Roders, A. (2014). Learning from a legacy: Venice to Valletta. Change Over Time, 2(4), 244-263. https://doi.org/10.1353/cot.2014.0022

\title{
KONTEKSTAS KAIP ARCHITEKTŪRINĖS KŪRYBOS PRIEMONIŲ RINKINYS IŠ TAM TIKRŲ URBANISTINIO PAVELDO APSAUGOS IR TVARAUS VYSTYMO PERSPEKTYVŲ
}

\author{
Eglè NAVICKIENE்
}

Santrauka

Kaip architektūros kokybès kriterijus, kontekstiškumas laikomas neapibrèžtu ir sunkiai naudojamu vertinant. Nepaisant nekonkretumo, kontekstiškumas laikomas vienu esminių reikalavimų architektūrineje kūryboje. Tad kas tai yra kontekstas architektūrinejje kūryboje? Straipsnyje nagrinèjamos skirtingos architektūrinio-urbanistinio konteksto sampratos kultūros paveldo apsaugos ir tvarkymo reiškinio požiūriu tam tikrais jo etapais pagal aktualias kategorijas. Kiekvienas nagrinètas etapas ar kategorija teikia vis kitokị architektūrinio-urbanistinio konteksto supratimą, priskirdami jam specifinị turinị, apimtị ir prasmes. Architektūrinio paveldo apsaugos požiūriu, kontekstu laikomos fizinių architektūrinių elementų - vizualiai suvokiamų statiškų objektų - gretimybės; prie konteksto derinamasi siekiant harmoningo ir pagarbaus santykio. Kultūrinio kraštovaizdžio požiūriu, kontekstas yra gamtos ir žmogaus veiklos sukurta aplinka, nuolat besikeičianti pagal vietoveje susiklosčiusius natūralius ir kultūrinius procesus; vykdant architektūrines transformacijas, tęsiami vietai būdingi procesai, sukauptos patirtys ir reikšmès. Istorinio urbanistinio kraštovaizdžio požiūriu, kontekstas yra nuolat besivystantys urbanistiniai, kultūriniai, socialiniai ir ekonominiai procesai aplinkoje, kurios kultūrinị unikalumą ir tapatumą vietos bendruomenès prisotina su vieta susietomis reikšmemis, patirtimis ir emociniais ryšiais. Šiuo atveju kontekstas taip pat yra praturtinamas nūdiene architektūrinès kaitos išraiška. Tvaraus vystymosi požiūriu, kontekstas yra kultūriniai, socialiniai, materialieji ir ekonominiai ištekliai bei šaltinis tradicinių žinių, veiksenos ir elgsenos modelių, kuriuos taikant ir tęsiant pasiekiamas darnesnis sambūvis su aplinka, kultūra ir klimato sąlygomis toje vietovejje, gerinantis vietos bendruomenès gyvenimo kokybę.

Reikšminiai žodžiai: architektūrinis kontekstas, kūrybinis projektavimas, kultūros paveldo apsauga, istorinis urbanistinis kraštovaizdis, istorinių miestų apsauga ir valdymas, tvari pletra, urbanistinis kontekstas. 